\title{
Menjadi Guru Aktif, Kreatif, dan Inovatif Dalam Pembelajaran Online
}

\author{
Darisman Henki Saputra Nst \\ E-mail: darismanhenki@gmail.com \\ *Program Studi Pendidikan Bahasa dan Sastra Indonesia, Universitas Riau
}

\section{Pengantar}

Dalam kegiatan pembelajaran disekolah melibatkan antara peserta didikan dan guru pada pelaksanaannya.aktivitas belajar mengajar yang dilakukan oleh guru dan peserta didik lebih menekankan pada pentingnya proses mendapatkan pemahaman terkait materi. Pentingnya proses dalam menemukan pemahaman ini ditunjang oleh berbagai hal baik iotu media, metode, maupun model pembalajaran yang berorientasi pada pemahaman peserta didik.

Sejak Indonesia dilanda pandemic covid-19 dikeluarkannya kebijakan pemerintah memalui Kementrian Pendidikan dan Kebudayaan bahwa seluruh kegiatan pendidikan dilaksanakan secara dalam jaringan dengan memanfaatkan berbagai teknologi yang tersedia. Ini tentunyu menuntut guru untuk mampu beradaptasi dan menemukan model pembelajaran yang selaras dengan teknologi yang digunakan.

Pembelajaran dengan bantuan komputer seperti menggunakan aplikasi bandicam, youtube, google classroom dan lain sebagainya memberikan kemudahan dalam proses pelaksanaan pembelajaran jika guru mampu memanfaatkannya sebaik mungkin. Menurut Wena dalam (Kristiawan, Aminudin, dan Rizki, 2021) keuntungan dengan pembelajaran berbantuan komputer yaitu memberi kesempatan memecahkan masalah, presentasi menarik, pilihan isi pembelajaran beragam, memotivasi siswa, menstimulasi metode mengajar, meningkatkan pemahaman siswa, memberi umpan balik, dan mengontrol kecepatan belajar.

Seorang guru yang memiliki pengetahuan yang lemah dan wawasan yang sempit dapat membuatnya sulit untuk aktif dalam menyampaikan gagasan terkait 
pembahasan. Selain itu, seorang guru di saat pembelajaran daring di tuntut mampu kreatif dalam menemukan berbagai metode atau model pembelajaran yang menyenangkan, selarasa dengan kreatif seorang juga harus kreatif dalam menenemukan berbagai inovasi guna menarik erhatian peserta didik terkait materi bahasan.

Tulisan ini dibuat dalam rangka mengoptimalkan pembelajaran daring saat pandemi Covid-19 berbasis aplikasi online pendukung pembelajaran. Tulisan ini dibuat agar seorang pendidik mampu menjadi aktif, kreatif, dan inovatif sehingga resiko terjadinya lose learning dan kurangnya antusias peserta didik dapat teratasi dengan baik.

\section{Tindakan yang Dilakukan}

Dalam mewujudkan seorang guru yang aktif, kreatif, dan inovatif tentulah harus dibarengi dengan berbagai aksi nyata dan usaha secara optimal guna ketercapaian materi bahasan. Seorang guru yang aktif, kreatif dan inovatif tentulah harus mampu mevairkan suasana dalam pelaksanaan kegiatan bisa itu dengan menanyakan pertnyaan ringan saat membuka kelas selanjutnya dibarengi dengan melakukan curah pengalaman dan pendapat terkait materi bahasan. Hal ini mampu menjadikan proses pembalajaran yang lebih komunikatif dan peserta didik bisa berperan aktif dan merekam memori materi dengan baik.

Memastikan kesiapan pendidik dan peserta didik juga sangatlah penting, jika terlihat peserta didik belum tertarik dengan materi bahasan tentunya guru harus sigap menciptakan inovasi agar perhatian peserta didik. Pada momen ini kesiapan seorang pendidik diuji agar bisa membuat suasana kelas yang aktif, kreatif, maupun inovatif.

Selanjutnya, coba untuk membagi peseta didik menjadi beberapa kelompok dan memberikan tugas membuat video terkait materi bahasan agar mereka mampu memecahkan masalah secara-bersama-sama. Berbarengan dengan itu pula mempertajam sisi kognitif dan psikomotor peserta didik karena dituntut aktif, kreatif, dan inovatif selaras dengan guru yang memberikan materi. 
Pembelajaran daring membuat guru tidak dapat melihat lansung bagaiman ekspresi dari peserta didik. Sehingga terkadang guru tidak dapat melihat lansung tingkat antusisas dari peserta didik terhadap materi yang diberikan. Maka dari itu, secara aktif guru mengajak peserta didik untuk mengaktifkan kamera sehingga suasana kelas terasa lebih komunikatif dan raut wajah peserta didik dapat terlihat dengan jelas serta guru dapat menimbang terkait ketercapaian tujuan pembelajaran.

\section{Sarana Pendukung}

Tak hanya tindakan yang diperlukan dalam pelakanaan belajar mengajar, tetapi sarana pendukung yang juga turut menjadi unsur penting dalam menciptakan guru yang aktif, kreatif dan inovatif. Beriku merupakan sarana pendukung dalam menjadi guru yang akti, kreatif, dan inovatif:

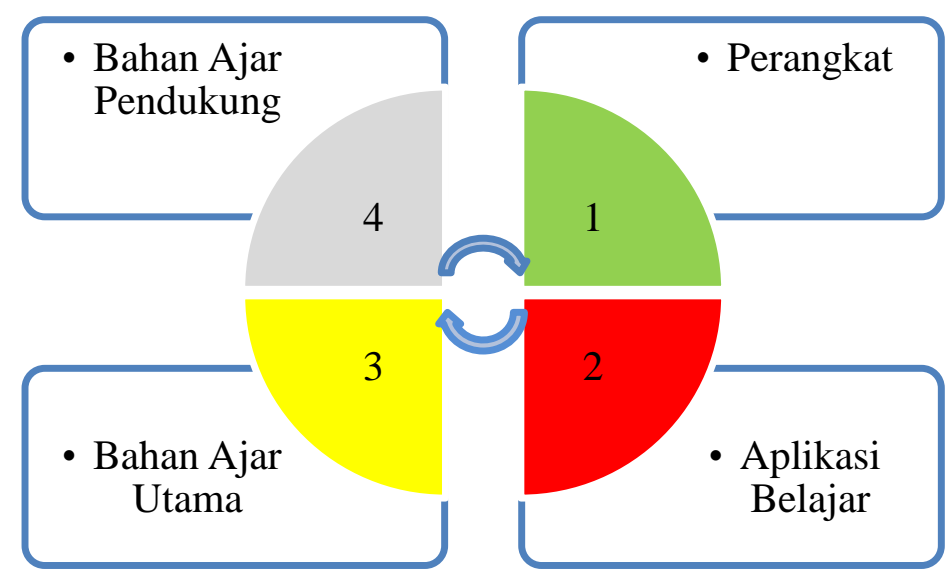

Gambar 1. Sarana Pendukung Guru Aktif, Kreatif, dan Inovatif.

1. Perangkat, dalam pelaksanaan pembelajaran daring perangkat merupakan saran pertama yang harus di siapkan seorang tengana pendidik, perangkat ini dapat berupa computer atau laptop, kuota internet serta jaringan internet yang memadai. Sehingga proses pembelajaran dapat terlaksana dengan baik.

2. Aplikasi belajar, penggunaan aplikasi belajar merupakan sarana umum yang sering digunakan guru dalam melaksanakan kegiatan pembelajaran, dapat berupa aplikasi Google classroom, Google meet atau zoom, dan beberapa aplikasi belajar lain yang dapat digunakan. 
3. Bahan ajar utama, sebagai seorang guru tentulah harus menyiapkan bahan ajar untuk digunakan dalam menyampaikan materi terkait. Bahan ajar utama ini merupakan sumber utama dari pembelajaran bisa berupa, buku ajar, aplikasi perpustakaan, situs-situs, dan bahan ajar terkait.

4. Bahan ajar pendukung, selain bahan ajar utama, guru juga harus mempersiapkan bahan ajar pendukung agar pelakasanaan pembelajaran dapat dilakukan dengan maksimal. Sebagai guru yang kreatif bahan ajar pendudkung dapat dengan memanfaatkan berbagai saran yang ada seperti aplikasi pengeditan video, youtube, dan lain lain.

\section{Tindakan Solutif}

Selain sarana pendukung, kembali guru dintuntu mampu kreatif dan sigap dalam menghadapai kendala dalam proses pelaksanaan pendidikan. Guru harus mampu menyiapkan solusi terhadap kemungkinan-kemungkinan yang dapat menjadi penghalang dalam proses pembelajaran.

Jika berhadapan dengan kendala terkait sarana pendukung pembalajaran guru dapat melakukan beberapa hal sebagai berikut:

1. Memberikan kuis ataupun memainkan permainan terkait pembelajaran sehingga pembalajaran dapat terlaksana dengan menyenangkan.

2. Bercerita untuk mencairkan suasana sehingga menarik kembali perhatian peserta didik.

3. Bersikap demokratis dengan memberikan pilihan kepada peserta didik.

4. Memberikan tugas dengan kalimat yang efektif.

5. Menanyakan alasan terkait kepada peserta didik karena tidak menghidupkan kamera.

6. Ajak peserta didik untuk bermusyawarah jika mendapati kendala yang krusial.

\section{Simpulan}

Sejak ditetapkannya kebijakan pemerintah melaksanakan pembelajarang daring guru dituntut harus mampu beradaptasi dan menjadi aktif, kreatif, dan inovatif. Mewujudkan guru yang aktif, kreatif, dan inovatif haruslah dibarengi 
dengan tindakan yakni curah pengalaman dan pendapat, memastikan kesiapan pendidik dan peserta didik, membagi peserta didik kedalam kelompok agar lebih komunkatif dan pemberian tugas terkait agar peserta didik mampu memcahkan masalah dan aktif dengan menghidupkan kamera.

Selain dibarengi tindakan tenaga pendidik juga harus mempersiapkan sarana pendukung dan pnyelesaian saat menemukan kendala dalam proses pelaksanaan pembelajaran. Saran pendukung antara lain perangkat, aplikasi belajar, bahan ajar utama, dan bahan ajar pendukung. Namun, pasti akan menemukan kendala terkait sarana pendukung tersebut dengan tindaka solutif, memberikan kuis, bercerita, bersikap demokratid, memberikan tugas, aktif bertanya, dan bermusyawarah dengan peserta didik.

\section{Referensi}

Joenaidy, A. M. (2018). Guru Asyik, Murid Fantastik!. Diva Press.

Kristiawan, M., Aminudin, N., \& Rizki, F. (2021). Optimalisasi pembelajaran daring berbasis aplikasi online bagi calon guru pendidikan anak usia dini. Jurnal Obsesi: Jurnal Pendidikan Anak Usia Dini, 5(2), 1905-1914.

Mustafa, M. N., \& Zulhafizh, Z. (2018). Information Mastery By Teachers As A Strategy To Succeed In The Implementation Of Teaching And Learning Activities. In International Seminar and Annual Meeting BKS-PTN Wilayah Barat 2018 (pp. 516-523), Palembang.

Mustafa, M. N., \& Zulhafizh. (2017). Building the Professionalism of Teachers as an Effort to Improve Education. In Husein, R, et al (Eds.), International Seminar and Annual Meeting 2017 Fields of Linguistics, Literature, Arts, and Culture, Medan, 449. 
*Data Penulis

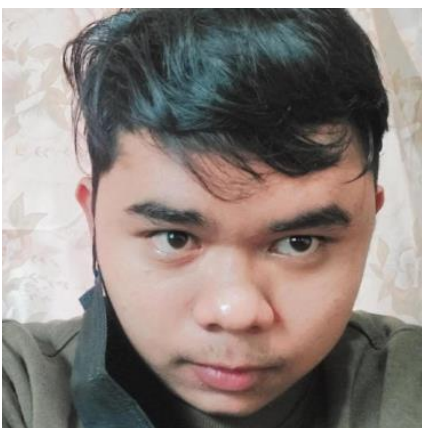

Kontak:

Hp/WA : + 6282294679124

Email : darismanhenki@gmail.com/darisman.henki3107@student.unri.ac.id
Darisman Henki Saputra Nst, lahir di Pekanbaru, 28 Januari 2002. Pada tahun akademik,2020-2021 Ia melanjutkan studi pada strata satu Jurusan Pendidikan Bahasa dan Seni di Program Studi Pendidikan Bahasa dan Sastra Indonesia FKIP Universitas Riau melalui jalur SBMPTN, dan sampai sekarang masih berstatus mahasiswa. Sederet prestasi beliau selama menjadi mahasiswa ialah juara 3 LKTIQ ikhwan FKIP Universitas Riau 2020, dan merupakan sekretaris divisi humas dan advokasi Himaprodi PBSI periode 2021-2022. 